\author{
Наташа С. ВУЛОВИЋ* \\ Институт за српски језик САНУ \\ Београд
}

Оригинални научни рад

Примљен: 26. 02. 2018.

Прихваћен: 23. 04. 2018.

\title{
АКСИОЛОГЕМЕ КАО ОДРЕДНИЦЕ У ФРАЗЕОЛОШКОМ РЕЧНИКУ ${ }^{* *}$
}

\footnotetext{
У раду се разматрају фразеографске методе и принципи класификовања фразеолошких јединица српског језика у одређеном типу фразеолошког једнојезичног речника. Фразеолошки аксиолошки речник као леме садржи вредности и антивредности, које формирају својеврсну аксиолошку парадигму.

Кључне речи: фразеографија, аксиологема, аксиолошки фразеолошки речник, фразеографија, аксиолошка парадигма, аксиолошки вектор, слот(ови).
}

Предмет овог рада јесте представљање могућих начина формирања аксиологема као одредница у типовима једнојезичног аксиолошког фразеолошког речника ${ }^{1}$.

Последње две до три деценије појму вредност своја истраживања посвећују не само филозофи него и научници из других дисциплина: културологије, историје, психологије, политике, педагогије и др. Разумевање вредности као поклапања објекта са представом о томе какав би тај предмет требало да буде сусреће се још код Платона и сматра се класичним. Вредност као интердисциплинарни појам означава позитивни или негативни значај објеката који нас окружују - за човека, социјалну класу, групу, за друштво у целини. Она се одређује њиховим учешћем у различитим сферама човековог живота, делања, интереса и потреба, као и у области друштвених односа. Одређује се критеријумима и начинима вредновања значаја тих објеката, израженим у етичким принципима и нормама, идеалима, поставкама, циљевима. Стари постулат о томе да је нека ствар вредна ако је ми желимо, у вези је са

\footnotetext{
"natasa.vulovic@isj.sanu.ac.rs; nativa8@gmail.com

${ }^{* *}$ Овај рад настао је у оквиру пројекта 178009 Лингвистичка истражсивања савременог српског језика и израда Речника српскохрватског књижевног и народног језика САНУ, који финансира Министарство просвете, науке и технолошког развоја Републике Србије.

${ }^{1}$ Идеја о изради аксиолошког фразеолошког речника и усмеравање размишљања у том правцу потекли су пре више година од ментора проф. Драгане Мршевић-Радовић.
} 
савременим аксиолошким натурализмом. Међутим, према схватању феноменологије, вредности нису особине (својства) ствари. На пример, постоји становиште према коме су носиоци етичких вредности - личности, а естетских - уметничка дела. Ј. Мукаржовски разликовао је вредности постојања, интелектуалне, етичке, социјалне и религијске вредности; Н. О. Лоски је бранио мишљење према коме се Бог схвата као више „самопоштовање”; М. М. Бахтин је у многообразности индивидуа видео мноштво „непоновљиво вредних личних светова”.

Нова парадигма у сагласности са антропоцентризмом као фокусом у савременој науци о језику скренула је пажњу лингвиста у правцу, како је то Апресјан приметио, „поимања да речи не функционишу саме по себи, већ представљају средства изражавања лично доживљене, перцепиране индивидуалне слике света у свом богатству њене суштине, особина, веза и односа, емоционално-оцењивачких нијанси и сл." (Апресјан 1995: 224). У складу с тим, интересовања лингвиста усмерена су на (про)цењивање и језичка средства којима се оно изражава као аксиолошка информација у свести језичке личности и заузима једно од важних места на мелиоративној/пејоративној скали оцене (Мирзоева 2001: 108).

Пишући о аксиологији у животном и језичком механизму, Арутјунова је 80-их година 20. века указала на чињеницу да се човек потпуно придржава одређеног (опредељеног) система вредности, делећи све на добро и лоше: добро и зло, срећу и несрећу, богатство и сиромаштво, врлину и порок, успех и пропаст, здравље и болест, добитак и губитак, што се одражава и у језику (Арутјунова 1984: 5). Тако се у савременој лингвистици, у оквиру словенске лингвокултурологије и фразеологије, проучава однос аксиолошких категорија вредности и антивредности, те се у радовима фразеолога појављују нови термини: аксиологема, лингвокултуролошка вредност, лингвоаксиологија, аксиолошка фразеологија, аксиолошки фразеологизми, аксиолошка информација итд. (Бајрамова 2013: 276-282).

Под вредношћу уопште могу се подразумевати општечовечанске вечне вредности (истина, праведност, доброта, лепота...) или конкретно-историјске вредности великих социјалних група (једнакост, демократија, државност), затим малих социјалних група (успех, богатство, занатство (пословност), самопоуздање), чиме се долази до свеобухватних, обједињујућих архетипских слика које функционишу у сазнању припадника једне језичке заједнице (нпр. живот, дом, љубав, лепота, мудрост, верност, породица, вера, домовина) (Пољакова 2008: 18).

Најпродуктивнији у словенској лингвистици су очекивано руски и пољски лексиколози и фразеолози ${ }^{2}$.

${ }^{2}$ На пример, то су радови које су публиковали Пудо Дорота (Aksyologia języka i komunikacji na komercyjnych kursach językowych dla dorostych (na przykładzie kursów języka francuskiego)), Ева Сиатковска (O polskim chudym i czeskim chudým z punktu widzenia semantyki i aksyologii), Haталија Вишњевска и др., док је на лексикографском плану важан рад Јежија Бартмињског који, након израђеног Пољског аксиолошког речника, ради са екипом лингвиста на изради Словенског аксиолошког речника. У руској лингвистици је много таквих публикованих радова из лингвокултурологије, етнолингвистике и фразеологије. Слична истраживања подстакнута су и у англо- 
Као резултати таквих истраживања у руском језику настали су савремени фразеолошки речници као што је велики фразеолошки речник руског језика с културолошким коментарима Веронике Телије из 2006. године (уп. Телија 2006) или речник који су израдили Алефиренко и Золотих 2008. године (Алефиренко/Золотих 2008). Поред поменутих лингвокултуролошких речника, за фразеолошку аксиологију посебно су значајни фразеолошки речници Казањске фразеолошке школе тј. Лујзе Бајрамове, који су конципирани двојако: као аксиолошки речници општег типа (Аксиологический фразеологический словарь русского языка) и као аксиолошки речници фразеологизамабиблизама (Аксиологический словарь фразеологизмов-библизмов на русском, украинском, белорусском, болгарском, польском, чешском, немецком, франиузском). Термин библизам односи се на све фразеолошке конструкције које се налазе у библијском тексту (директне) и оне настале на основу перцепције (индиректне), те се може рећи да обједињује језичке јединице античког, фолклорног хебрејског, семитског или филозофског порекла са простора старог јудеохришћанског Истока. Такође, израђен је и објављен и вишејезични аксиолошки речник општег типа: Аксиологический словарь славянской фразеологии (на примере русских, болгарских и украинских идиом).

Последњих десетак година и у српској лингвистици се такође појављују радови посвећени проучавању језичких средстава за изражавање вредности и то у оквирима лексикологије, тј. етнолингвистике, те је 2015. године изашао зборник радова $O$ вредностима у српском језику, где су радови посвећени неким од концепата лексема које означавају вредности, као што су: дом, рад, слобода, част, живот, домовина, мајка, Европа и др., али и са фразеолошког аспекта, где су проучаване концептуализације вредности истина и антивредности лаж у српској фразеологији (уп. Мршевић-Радовић 2008), као и концепт части (в. Пејановић 2010), љутње (уп. Штрбац 2013).

При фразеографској обради фразема у различитим врстама речника нису исти захтеви. Обавезне компоненте речничког чланка су: основна (базна) форма фразеолошке јединице, дефиниција и илустративни материјал употребе. Затим се ту могу наводити још и: граматички знаци (нпр. типови синтаксичке везе, рекција), функционално-стилистичке ознаке (употребна вредност), постојећи варијантни облици и сл. У фразеолошким речницима, у зависности од типа, налазе се и још неке факултативне компоненте: упућивања, синоними, допунски коментари, који могу бити етимолошко-историјског, књижевно-уметничког, лингвокултуролошког и сл. садржаја. Пошто је један од важних проблема лингвоаксиологије израда аксиолошког фразеолошког речника, у овом случају српског језика, постављају се питања која се тичу фразеографске кодификације (Бушуј 2010), тј. теоријско-практичне интерпретације фразеолошке грађе: а) одређивање садржаја и структуре, б) питања корпуса, в) идентификација и селекција, г) прецизирање аксиолошке парадигме (одређење базне фразеоформе и методе навођења), г) употре-

саксонској лингвистици (нпр. Phraseology and Culture in English у зборнику Пола Сканадера из 2007. године), док се идејне поставке А. Вјежбицке сагледавају у радовима Џефрија Вилијамса, у зборнику Phraseology: An interdisciplinary perspective. 
ба квалификатора, д) општи семантичко-дефиницијски параметри, као и е) илустративни материјал.

Садржај и структура аксиолошког фразеолошког речника српског језика могу бити конципирани као код речника општег типа или речника аксиолошких библизама. То значи да лематски део чине аксиологеме, које могу бити библизми (примарни и секундарни) - или аксиологеме уопште (у чијем би саставу били и библизми поред осталих, с обзиром на јудеохришћанску провенијенцију, културно наслеђе и традицијски синкретизам Срба, а и на чињеницу да је Књига над књигама извор и акумулатор многих вредности и антивредности Старог света). Постојећи дескриптивни и фразеолошки речници српског језика (РЈА, РМС, РСАНУ, РСЈ, ФРХСЈ, ФРСЈ), Даничићеве и Вукове пословице чинили би основни корпус из којег би се ексцерпирала, идентификовала и селектовала фразеолошка грађа и формирао корпус у ширем смислу (уже и шире фразеологије, тј. фразеологије и паремиологије). Контролне корпусе чинили би други извори (Народне умотворине ЛМС, Библијски изрази и пословице итд.).

При сличним истраживањима, лингвисти истичу важност резултата дијахронијских истраживања у језику, дакле дела корпуса из старије књижевности, јер сазнања о ономе што је било вредновано у прошлости чине механизам формирања културолошких вредности (Титкова 2003: 85). Због тога би се као додатан корпус могао размотрити опус српских средњовековних хагиографских дела, али и дела преводне књижевности, као што су: апокрифи, византијске приповетке, романи, у преводима на савремени српски језик (који су се читали и препричавањем или проповедањем сазнавали и ширили у прошлим вековима).

Аксиолошку парадигму формирају скупови аксиологема формирани према утврђеним параметрима, који су међусобно супротстављени, а обједињени према постојању позитивног (одобравајућег) или негативног (непожељног) аксиолошког вектора (Бајрамова 2009: 29-30). Тај аксиолошки вектор који је позитиван или негативан може се мењати у процесу фразеологизације (установљавања фразеологизма). Аксиологеме су груписане као јединице којима се изражавају основне конвенционалне вредности и антивредности кодиране у сазнању, култури и језику српског (словенског) социума. У постојећим концепцијама фразеолошких речника представљају су у оквиру одабраних 10 основних, базичних дијада: живот - смрт, здравље - болест, срећа - несрећа, домовина (своје) - туђина (туђе), рад - одмор (нерад, лењост...), богатство - сиромаштво, памет - глупост, истина -лаж, смех - плач, рај - пакао. Ова парадигма има слотну ${ }^{3}$ структуру, која се одликује гипкошћу (флексибилношћу), а зависи од фразеолошког материјала, што значи да се као слотови појављују хипоними (унутар поменутих хиперонима као вредности / антивредности) (Бајрамова 2011: 12). Односно, у оквиру одређених дијада подразумевају се, обухватају се и други семантички хи-

\footnotetext{
${ }^{3}$ Термин слот је англицизам који потиче из рачунарске терминологије, а користи се у савременим фразеолошким/фразеографским радовима. У основном значењу означава „пукотину, узан отвор" (Бајрамова 2011).
} 
поними, али уз ограничења, регулисана применом семантичких параметара. На пример, витална вредност живот, осим оних које директно изражавају начин живота, где би спадале аксиологеме: као маче у цегеру, као мали бог, осећати се добро као овца међ' вуковима, подразумева следеће хипонимеслотове: Жив/о. Дете. Крвно сродство. Узраст. Дужина живота. Средства за опстанак. Духовни живот. Судбина итд., тако да би нпр. овде припадале и фраземе Адамов век или наносио се душе. Тако би под антивредност смрт, аксиологеме биле: отићи у Аврамово крило, отићи богу на истину, испустити душу, али и оне које се односе на самрт (мирисати на панахију, носити кољиво у иепу), убиство, братоубиство (послати некога богу на истину - на онај свет, испојати (отпевати) за душу некоме, угасити свећу некоме и др.). Што се тиче библизама, ту би се навео нпр. секундарни библизам пролити невину крв, мотивисан описом библијског догађаја. Тако би под моралноетичку вредност истина (Сан је лажа, Бог је истина) потпадала и искреност (искрен као Мајка Божија), а под антивредност лаж (лаже као Турчин, (као Грк, као календар); лаже и кад се исповеда; искрен као Циганин) било би и лицемерје (Јудин пољубаи), притворност (нпр. изрека: и курјак је овиа кад у замке падне, бити пријатељ на језику, као и библизам - вук у овчијој кожи).

При навођењу основног облика аксиологеме (базне фразеоформе) треба водити рачуна о нормативној промени форме, о поретку распореда компонената, фиксираној форми, варијантности и унутрашњим синтаксичким везама, а то би значило и нпр. о томе да ли се глаголско-именичке синтагме (уколико је то у складу са језичким осећањем) наводе у инфинитиву, а у другачијим случајевима у забележеном гл. облику, али без инверзије компонената унутар тог структурног облика и уз навођење рекције (Бушуј 2010: 47-52).

Употреба квалификатора се односи на етимолошку ознаку (по потреби), извор (ако се ради нпр. о Библији, античкој, латинској пословици, басни и сл.), као и на функционално-стилистичко раслојавање (ир., шаљ., презр., разг., вулг., шатр. и др.), указујући на употребну вредност аксиологеме (књижевни језик, разговорни, неутрални и др.). Критеријуми формирања дефиниције тичу се описног, синонимног или упућивачког начина. На то утичу многи интерлингвистички и граматички фактори, али и историјско-етимолошки, етички, митолошки, затим однос оцене као обрнуте стране вредности на филозофском плану, стилистичке карактеристике, ејдо-ментални код, као и др. лингвокултуролошки параметри.

Као што је на почетку поменуто, вредности и антивредности могу бити животне, хедонистичке, социјално-утилитарне, морално-етичке, материјалне, когнитивне, емоционалне, религијске (Бајрамова 2013: 276).

Илустроваћу примером представљање материјалне вредности богатство и материјалну антивредност сиромаштво. Ту би спадали слотови: богата земља, ситост, славити (славље), новач као отелотворење богатства, митско богатство, неопходност итедње, стицана, чувања за ирне дане, односно / сиромашан човек, глад, немање станишта, милосрђе према сиромашнима, помоћ. Библизам у форми именичке синтагме: обећана (обетована) земља има примарно значење које је библијско и није фразеолош- 
ко: „Палестина (у Библији)”, али има секундарно значење које је фразеолошко: „богата и срећна земља, крај, место”. Ово значење настало је метафоричко-асоцијативним путем и засновано на библијској причи Старог завета о лутању Јевреја. Занимљиво је то да библизам у оваквом облику не постоји у Старом, већ у Новом завету, и то у делу посланице Јеврејима Св. апостола Павла, у којем се говори о вери: „Вјером дође Авраам у земљу обећану, као у туђу, и у колибама живљаше с Исаком и с Јаковом, сунашљедницима обећања тога (Јевр. посл. св. ап. Павла 11, 9). Имају га и многи други језици,

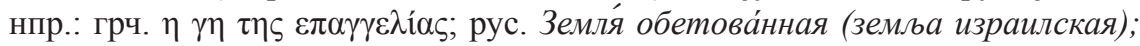
енг. the promised land; нем. das gelobte Land итд4.

У уској етимолошко-семантичкој вези с претходном стоји још један директни библизам мед $\boldsymbol{u}$ млеко, који у савременом српском језику постоји у две варијанте - с компонентама мед и млеко у напоредном односу, односно као глаголско-именичка бити мед и млеко и тече, точи мед и млеко. Она се у највећем описном речнику српског језика Речнику САНУ дефинише и потврђује овако: „мед и млеко (често уз глагол (по)тећи) благостање, изобиље; бити, имати свега у изобиљу. - Стизали су чудни гласови из Колашина ... није им се могло вјеровати. Напротив - замишљао сам да је тамо мед и млијеко (М. Лалић). Не лете овуда печене шеве, нити тече мед и млеко, него се ваљано крвавимо (Б. Ћосић). Не кажем ни ја да је увек и свуд баш текао мед и млеко (С. Сремац)".

Овај библизам појављује у већем броју цитата из Старог завета (16), описујући управо обећану земљу Јудеја: „И сиђох да га избавим из руку Мисирских, и да га изведем из оне земље у земљу добру и пространу, у земљу гдје млијеко и мед тече (Др. Мојс., 3, 8); Да бих испунио заклетву којом се заклех оцима вашим да ћу им дати земљу у којој тече млијеко и мед, како се види данас. А ја одговорих и рекох: амин, Господе (Јер. 11, 5)"`. Као што је уочљиво, облик у оригиналу је синтаксички инверзиван у односу на формирану актуелну фразеоформу (глаголско-именичку конструкцију с месном допуном) у српском језику (точи негде) мед и млеко. И ово је интернационални библизам, нпр.: лат. Eduxit patres nostros de terra Aegypti dare nobis terram fluentem lac et mel; pус. (земля где) течет (текут) молоко и мед; енг. land of milk and honey; нем. (das (ein) Land) wo Milch und Honig fließen. Стара метафора о представи обиља сликом млека постојала је и у словенској

${ }^{4}$ Ови примери цитата се наводе према издању Библија. Стари и Нови завет (превод: Ђ. Даничић, B. Караџић), Leo commerce, Београд 2002. Скраћенице су наведене према том издању.

${ }^{5}$ И рекох вам: ви ћете наслиједити земљу њихову и ја ћу вам је дати у државу, земљу у којој тече млијеко и мед. Ја сам Господ Бог ваш, који вас одвојих од других народа (Тр. књ. Мојс. 20, 24). Мало ли је што си нас извео из земље у којој тече млијеко и мед да нас побијеш у овој пустињи, него још хоћеш да владаш над нама? (Четв. Мојс. 16, 13). Чуј дакле, Израиљу, и гледај да тако чиниш, да би ти добро било и да бисте се умножили веома у земљи у којој тече млијеко и мед, као што ти је рекао Господ Бог отаца твојих. (Пета књ. Мојс. 6, 3). Јер четрдесет година иђаху синови Израиљеви по пустињи докле не помрије сав народ, људи војници, што изидоше из Мисира, јер не слушаше гласа Господњега, те им се закле Господ да им неће дати да виде земљу, за коју се заклео Господ оцима њиховијем да ће нам је дати, земљу, гдје тече млијеко и мед (Ис. Нав. 5,6$)$. Онога дана подигох им руку своју да ћу их одвести из земље Мисирске у земљу коју сам пронашао за њих, гдје тече млијеко и мед, која је дика свијем земљама (Јез., 20, 6). 
митологији, потврђују је етиолошке легенде и приповетке Источних и Јужних Словена о млечним рекама које теку у царство мртвих, тј. представљају пут на онај свет (ЕРСМ 2001: 360-362). Млеко у хришћанској симболици означава савршену духовну храну (Мршевић-Радовић 2008: 25). У руском језику забележена је шаљиво-иронична именичка конструкција фолклорног порекла молочные реки и кисельные берега, која потиче из усмене традиције, али је мотивациона слика о реци млека, меда, вина и сл. универзалан симбол материјалног богатства и безбрижног живота (Мокијенко 2007: 326).

И у другим језицима је углавном распоред именичких компонента: млеко и мед, док је у српском језику најпре краћа, па дужа форма. Али једна другачија конструкција из библијског текста има у фразеоформи облик: мед и млеко: „С усана твојих капље сат, невјесто, под језиком ти је мед и млијеко, и мирис је хаљина твојих као мирис Ливански (Песма над песмама 4,11$)$ ". Одатле потичу другачије следеће фраземе српског језика: говорити мед $u$ млеко у значењу: „приказивати нешто улепшано, говорити о нечему примамљиво, слаткоречиво”; обећавати мед и млеко „обећавати много, све најбоље, најлепше" и мед ми (му, ти, јој и сл.) тече из уста, с језика, с усана „каже се (обично с ир. призвуком) за онога ко говори лепо, слаткоречиво, много и свашта примамљиво обећава” (уп. Мршевић-Радовић 2008: 24-26).

На овом месту треба указати на оно што је Титкова, између осталих, констатовала о потреби дијахронијског сагледавања. Наиме, у Житију деспота Стефана Лазаревића (у преводу на савремени језик Г. Јовановић) Константин животописац је, сасвим сигурно не случајно, заједно навео два библизма - у истој реченици: „Овај (Деспот) засија, дакле, од Далмације Дакије, (земље) данашњих Срба, где многи у последње време процветаше, о којима ће у родослову (бити) речи. И ова (земља) не само да као она обећана, точи мед и млеко, него (изгледа тако) као да је у себе примила и повезала четири годишња доба и ваздух и из себе их даје осталима (ЖСЛ 19)". Дакле, облик је у оригиналном тексту мед и млеко, што указује на већ оформљену конструкцију (калк) у српском књижевном језику тог времена, што значи да је он већ тада прихваћен облик. Ово опет значи да би неопрезна констатација да је реч о каснијем калку из неког од европских језика насталом преводом књижевности 18. и 19. века на српски језик била нетачна. Како се библизмима називају све фразеолошке конструкције које се налазе и у апокрифима, вероватно је да се фразема мед и млеко раширила у језику захваљујући популарности апокрифних текстова, какав је нпр. старозаветни апокриф Књига o Еноху из 2. века пре Христа настанак каснијих апокрифа (као што је апокриф Књига Сирахова): „земља у којој је мед и млеко".

${ }^{6}$ Постојао је у три варијанте (опширна, прелазна, скраћена) и написан на три језика - хебрејском, грчком (није сачуван оригинални превод, сачуван је етиопски примерак, тачније коптски, као и словенски препис превода са грчког) и латинском. У српскословенском препису се описују рај и пакао, па се при опису дела раја налази реченица: Ту су и два извора из којих тече млеко и мед, уље и вино (Јовановић Т., Енох 8,6). 
Занимљиво је да Фразеолошки речник бугарске академије наука бележи само фразему: буг. мед и масло ще потече. У Св. писму само се на једном месту као симбол богатства помињу мед и масло - то је у књизи о Јову, где се говори о лицемерима и безбожницима: „Неће видјети потока ни ријека којима тече мед и масло (Јов, 20, 17)"”. Овде се лексема масло појављује у секундарном значењу „маслиново уље, уље које се добија цеђењем маслина” (РСАНУ), дакле реч је о биљном маслу и о маслиновом уљу као посебно вредној супстанци (уп. нпр. свештати дрвена масла (некоме) у: Вуловић 2015: 108).

Материјалну антивредност сиромашан илуструју аксиологеме попут: нема за шта пас да (га, је) уједе, нема леба да једе, немати ни крста божијега (критене соли), бити голе душе, сиромашан као ирквени миш.

Наравно да би се развој формирања и измене семантике вредности и антивредности могао боље сагледати обухватнијим приступом, јер ако се нпр. посматрају аспекти у којима се говори у библ. тексту о богатству, биле би издвојене идеје о преваги важности духовног над материјалним богатством, тј. о њиховој неспојивости (Не можете служити богу и Мамону/Мамони - божанство богатства), становишту да је превелика љубав према новцу погубна, не узимајући у обзир средства за живот од свог рада - на земљи (лењост је антивредност у Библији), а свеобухватни материјал би дао увид у савременији прагматичко-оцењивачки однос изражен у језику.

Уколико се размотре успостављене дијаде у постојећим аксиолошким речницима Л. Бајрамове и упореде се с првобитним наведеним опозицијама код Арутјунове, постава се питање да је последња рај - пакао под којом се подразумевају религијске вредности и антивредности могла бити слот у оквиру шире, а важне дијаде добро - зло (лоше), а не обрнуто, и да под рајем и паклом буду наведене оне са значењем доброг и лошег, јер дихотомија добро - зло, лоше није искључиво религијска.

Илустровању истраживања у словенском свету одговара и већ позната чињеница да пољска и руска лингвистика имају и речнике библизама, а и различите лингвокултуролошке и аксиолошке речнике. С обзиром на значај израде речника као важних начина у процесу очувања лингвокултуролошких вредности уопште, као и на чињеницу да корпус српског језика није ушао у поменути већ објављени Аксиолошки речник словенске фразеологије (можда би и могао бити у неком следећем издању), неопходно је почети припреме за израду Аксиолошког фразеолошког речника српског језика.

\footnotetext{
${ }^{7}$ Примарно значење лексеме масло у српском језику јесте млечни производ који се издваја из млека или павлаке бућкањем (или иентрифугирањем), маслаи, бутер. Дакле, друго значење именичке компоненте семантички је у вези са уљем биљног порекла, тј. маслиновим уљем, а Даничић је ову реч буквално превео онако како је и у латинској Вулгати - латинском лексемом butyrum.
} 


\section{ИЗВОРИ}

Даничић/Карашић 2002: Ђ. Даничић, В. Караџић, Библија. Стари и Нови завет, Београд: Leo commerc.

Јовановић 2005: Т. Јовановић, Апокрифи. Старозаветни, према српским преписима. Апокрифи. Новозаветни, Стара српска књижевност у 24 књиге, књ. 23, Београд: Просвета-Српска књижевна задруга.

\section{ЛИТЕРАТУРА}

Алефиренко/Золотих 2008: Н. Ф. Алефиренко, Л. Г. Золотых, Фразеологический словарь русского языка: Культурно-познавательное пространство, Москва: Элпис.

Апресјан 1995: Ю. Д. Апресян, Образ человека по данным языка: опыт системного описания, Изабраные труды 2, Языки русской культуры, Москва.

Арутјунова 1984: Н. Д. Арутюнова, Аксиология в механизмах жизни и языка, Проблемы структурной лингвистики, Москва: Наука, 5-23.

Бартмињски и др. 2015: Ј. Бартмињски и др., О вредностима у српском језику (ур. Дејан Ајдачић), Београд: Алма.

Бајрамова 2009: Л. К. Байрамова, О проекте Славянского фразеологического словаря: универсально-уникальный, историко-этимологический, аксиологический параметры, Проблемы истории, филологии, культу$p b$, Научный журнал РАН, Под ред. Н. Г. Абрамзона, Москва-Магнитогорск-Новосибирск: Издательство ООО „Аналитик”, 184-188

Бајрамова 2011: Л. К. Байрамова, Аксиологический фразеологический словарь русского языка, Издание 2-е, Центр инновационных технологий, Казань.

Бајрамова 2013: Л. К. Байрамова, Отражение в библейских текстах ценностей и антиценностей и отсутствие некоторых их корреляций с эпизодами современной жизни, Филологические науки. Лингвистика, Казань, $136-140$.

Бушуј 2010: Т. А. Бушуй, Основы современной теорији контрастивной фразеографии, Вестник Челябинского государственного университета, 29, Филология. Искусствоведение, 47-52.

Вуловић 2015: Н. Вуловић, Српска фразеологија и религија, Монографије 23, Београд: Институт за српски језик САНУ.

ЕРСМ 2001: Словенска митологија - енииклопедијски речник (ред. Светлана М. Толстој, Љубинко Раденковић), Београд: Zepter book world.

Мирзоева 2001: Л. Ю. Мирзоева, Аксиологическая и функционально-стилистическая характеристика слова. Текст. Структура и семантика: т. 2, МГОПУ им. М. А. Шолохова, 108-113.

Мокијенко 2007: В. М. Мокиенко, Образы русской речи, Издательство „Флинта”, Москва: Издательство „Наука”. 
Мршевић-Радовић 2008: Драгана Мршевић-Радовић, Фразеологија и наиионална култура, Београд: Друштво за српски језик и књижевност Србије, Филолошки факултет.

Пејановић 2010: А. Пејановић, Етнокултурни концепт част у Горском вијениу, Дани Његошеви 2008/2009, Никшић, 51-66.

Пољакова 2001: А. А. Полякова, Образование и культура (аксиологический аспект), Вестник ОГУ 1 (4), 9-18.

PMC: Речник српскохрватског књижевног језика (I-VI), Нови Сад: Матица српска - Загреб: Матица хрватска, 1967-1976.

РСАНУ: Речник српскохрватског књижевног и народног језика (1-19), Београд: Институт за српски језик САНУ, 1959- .

PCJ: Речник српскога језика, Матица српска, Нови Сад, 2007.

Телија 2006: В. Н. Телия, Большой фразеологический словарь русского языка: Значение. Употребление. Культурологический комментарий, Москва: АЦТ-Прес Книга.

Титкова 2003: О. И. Титкова, О перспективах лингвистического исследования рекуррентных единиц лексикона, Филологические науки, 2, 79-86.

Штрбац 2013: Г. Штрбац, Концептуализација љутње у српској фразеологији, Зборник радова у част проф. Вери Васић, Нови Сад: Филозофски факултет у Новом Саду, 111-128.

Наташа С. Вулович

АКСИОЛОГЕМЫ КАК ЛЕММЫ В ФРАЗЕОЛОГИЧЕСКОМ СЛОВАРЕ

Резюме

Предметом исследования в настоящей работе являются фразеологические методы и принципы классификации фразеологических единиц сербского языка в конкретном типе фразеологического одноязычного словаря. Фразеологический аксиологический словарь как леммы содержит ценности и антиценности, которые образуют специфическую аксиологическую парадигму.

Ключевые слова: фразеология, аксиология, аксиологический фразеологический словарь, фразеография, аксиологическая парадигма, аксиологический вектор, слот(ы). 